\title{
Forbidden fire: Does criminalising fire hinder conservation efforts in swidden landscapes of the Brazilian Amazon?
}

\author{
Rachel Carmenta $^{1,2}$ (D) | Emilie Coudel ${ }^{3,4,5} \mid$ Angela M. Steward ${ }^{6}$
}

${ }^{1}$ Department of Geography, University of Cambridge Conservation Research Institute, University of Cambridge, Cambridge, UK

${ }^{2}$ Lancaster Environment Centre, Lancaster University, Lancaster, UK

${ }^{3}$ CIRAD, UR Green, Montpellier, France

${ }^{4}$ Embrapa Amazônia Oriental, Belém, Pará, Brasil

${ }^{5}$ Centro de Desenvolvimento Sustentável, Brasília, Brasil

${ }^{6}$ Universidade Federal do Pará, Belém, Pará, Brasil

\section{Correspondence}

Rachel Carmenta

Email: rachelcarmenta@gmail.com

\section{Funding information}

Darwin Initiative, Grant/Award Number: 17-023; NERC-ESRC, Grant/Award Number: ES/F012500/1; Instituto Nacional de Ciência e Tecnologia-Biodiversidade e Uso da Terra na Amazônia, Grant/ Award Number: CNPq 574008/2008-0; H2020 Marie Skłodowska-Curie Actions, Grant/Award Number: 691053; CGIAR Research Program on Forests, Trees and Agroforestry (CRP-FTA); French National Research Agency, Grant/Award Number: ANR-13-AGRO-0003
Global environmental change has motivated multiple interventions in pursuit of sustainable outcomes within tropical forest landscapes. Fire is recognised as a key stressor facing forest conservation efforts. Large-scale accidental fires are increasingly prevalent across the forested tropics, generating negative impacts across sectors and scales. Policy responses to mega-fires in the Brazilian Amazon have been diverse but all are dominated by an anti-fire narrative that highlights long-stigmatised smallholder agricultural practices. Despite forest conservation initiatives and fire management policies, escaped fire (wildfire) remains pervasive. Forest conservation initiatives are often situated in contexts where swidden agriculture prevails, generating a need for an improved understanding of the interplay between fire management and conservation initiatives on the ground. We explore these dynamics through a case study approach in three leading forest conservation initiative types, situated across diverse contexts in the Brazilian Amazon: a Reduction of Emissions of Deforestation and Degradation (REDD+) site (in Middle Solimões region), an extractive reserve (RESEX) (in Arapíuns region), and a Green Municipality Pact (GMP) (in Paragominas). Between sites, climate and colonisation histories vary, yet all demonstrate that farmers experience the burden of escaped fire, attesting to the failure of fire management policies and suggesting that fire (as currently managed) threatens forest conservation goals. Restrictive fire management policies do not replace the necessity of fire-based agriculture and rather serve to disempower swidden farmers by making burning increasingly illicit. We show that awareness of fire-free alternatives exists, yet experience is limited and constraints are considerable. We argue that marginalising fire use in the context of forest conservation initiatives contributes to a legacy of failed interventions and jeopardises partnerships between communities and conservation practitioners. Finally, we suggest that given the absence of imminent and viable fire-free alternatives, particularly in sites where swidden and conservation collide, a new model of fire warrants experimentation.

\section{K E Y W O R D S}

Agriculture, human dimensions, policy practice gap, REDD+, reserves, wildfire 


\section{1 | INTRODUCTION}

The human population is dependent on ecosystem services which are being degraded at a globally significant scale (Costanza et al., 2014). Tropical forests are a focal point of dramatic land-use change, largely associated with land clearance often involving intentional management of fire (from small to large scale), which can nevertheless escape creating uncontrolled "wildfires" (Aragão \& Shimabukuro, 2010; Soares-Filho et al., 2012). Once a relatively fire-free biome, the Brazilian Amazon now experiences frequent and extensive wildfires (Alencar et al., 2015; Cardoso et al., 2003; Cochrane \& Barber, 2009). Wildfires exemplify the governance challenges associated with complex social-ecological systems (Carmenta et al., 2011) and are expected to become a larger challenge in the future due to extended fire weather seasons, increased ignition sources, and positive feedbacks that favour fire generated by forest fragmentation and previous fire activity (Hardesty et al., 2005; Jolly et al., 2015; Nepstad et al., 2001).

In response to chronic rates of forest loss and degradation, diverse forest conservation interventions have been implemented across the Brazilian Amazon. These range from the classic protected area model to integrated policy approaches (e.g., the Programme to Control Deforestation in the Amazon) that solicit sanctions (e.g., economic boycotts) on deforesting municipalities (Assunção et al., 2015). Sustainable use reserves aim to achieve conservation through reconciliation with sustainable development. More recently, incentive programmes, including Reduced Emissions from Deforestation and Degradation (and associated co-benefits) (REDD+) aim to induce conservation through conditional rewards (Gebara \& Agrawal, 2017).

The comparative performance of forest conservation initiatives is a research topic of much debate (Bruner et al., 2001; Engel et al., 2008; Ferraro \& Hanauer, 2014; Joppa et al., 2008; Nelson \& Chomitz, 2011; Nepstad et al., 2006), within which fire is identified as a key stressor, although it is often overlooked in their design (Barlow et al., 2012; Friess et al., 2015). Despite the importance of reserves for conservation, sustainable development and stabilising climate change (Ricketts et al., 2010; Silvestrini et al., 2011; Soares-Filho et al., 2010), their effectiveness at mitigating fire prevalence is not fully understood (Morello et al., 2017). In some cases, reserves show a decline in fire; in others, reserves do not affect fire density or fire management (Carmenta et al., 2016; Nelson \& Chomitz, 2011; Nepstad et al., 2006). Different approaches to conservation necessitate particular approaches to fire management because of distinctions such as the presence (or absence) of smallholders using fire in swidden agricultural systems.

Policy responses to extensive forest fires in the Brazilian Amazon have also been diverse and were initially catalysed by the extreme forest fire events in 1997/1998. These "mega-fires" captured international attention and secured conditional loans (e.g., from the World Bank) in support of anti-fire policies (Sorrensen, 2009). A shift in policy logic occurred in the 2000s when fire-free agriculture was promoted through international partnerships (Denich et al., 2004; Joslin et al., 2011; Pedroso et al., 2008; Sommer et al., 2004). Some interventions explored "best-practice" fire management in collaboration with smallholder communities, but these did not scale up (Carvalho et al., 2009). Since 2009 Brazilian fire policy returned to a command-and-control type of approach, along with the ban-surveillance-sanction model effective in reducing deforestation (Morello et al., 2017). This phase has included states beyond the deforestation frontier also enacting fire restrictions (e.g., Acre's Zero Burn policy) (Rodrigues, 2011).

Across the forested tropics fire policy is largely situated within a pervasive anti-fire rhetoric (Carmenta et al., 2013; Carvalheiro, 2004; Costa, 2006; Harwell, 2000; Mathews, 2005). Anti-fire discourse targeting smallholders exists across the tropics from South America, to Asia and Africa (Carmenta et al., 2017; Harwell, 2000; Kull, 2002; McDaniel et al., 2005). The prevailing discourse is one of nefarious fire within which fire-based agriculture (and its associated practitioners) are systematically discredited (German, 2010). The burdens of escaped fire underwrite the discourse, and today relate primarily to the globally significant quantities of carbon emissions generated (Gatti et al., 2014; Phillips et al., 2009). Beyond carbon emissions, burdens include losses in agricultural and plantation-based investments (Bowman et al., 2008; Gaveau et al., 2017), national revenues (de Mendonça et al., 2004), biodiversity (Barlow et al., 2016) and public health (Shannon et al., 2016; Smith et al., 2014).

The anti-fire rhetoric, however, disregards the local utility, historic importance and cultural relationships to fire, which are associated with intentional fire use (Carmenta et al., 2013; Carvalheiro, 2004; Costa, 2006); rather, it situates all fire as bad, and in so doing, conflates distinct fire types (i.e., intentional and accidental). Conflating fire types impedes our understanding of the drivers of, and subsequently, the policy solutions to, tropical wildfire and contributes to the formulation of policies intent on fire restriction. Restrictive policies can serve to further disempower already marginalised groups (Carmenta et al., 2013), and can be used to advance the power and control of established hierarchies (Mathews, 2005). Additional factors make prohibitive approaches attractive, including the challenges of defining attribution (Gaveau et al., 2017), difficulties of implementing licensing requirements and weak processes surrounding liability cases in court (Mistry, 1998). 
The standard model of forbidden fire precludes initial dialogue and meaningful experimentation of possible alternatives that may empower traditional land management and practitioners while also preventing fire escape (wildfire) (McDaniel et al., 2005; Padoch \& Pinedo-Vasquez, 2010). Swidden farmers employ a series of techniques to manage intentional fire and prevent wildfires (Carmenta et al., 2013; Denevan \& Padoch, 1987; McDaniel et al., 2005). In tropical savannah regions where fire plays an adaptive role in ecosystem functioning, traditional fire management, often consisting of controlled fires in specified areas, not only maintains ecological integrity, but can mitigate wildfires (Eloy et al., 2018; Sletto, 2008; Sletto \& Rodriguez, 2013). While not without conflict, traditional and indigenous peoples living in savannah regions are increasingly recognised for their knowledge of fire management, and have become stakeholders in discussions of fire management policy, especially in conservation areas orientated towards ecosystem protection (Eloy et al., 2018; Mistry et al., 2016; Schmidt et al., 2016).

In tropical forest biomes fire is neither natural nor necessary from an ecological perspective, and fire use is resolutely castigated. Yet, the anti-fire approach has underperformed (Carmenta et al., 2016; Cochrane \& Barber, 2009). Further, the absence of available alternative agricultural technologies combined with the contemporary context of changing forest ecologies (e.g., fragmentation and degradation), and increasingly flammable landscapes, suggest that management methods require urgent attention and adaptation to secure improved performance (Moran et al., 2006; Nepstad et al., 2008; Nepstad et al., 2001). We are therefore interested in assessing the hypothesis that the restriction of fire use decreases the potential of farmers to adapt their fire management practices and jeopardises their livelihoods and their contribution to forest conservation, thus warranting an alternative solution.

We ask the following research questions: what are the fire management policies within the conservation sites and what are the burdens of wildfire? What is the importance of fire to smallholders and what are the alternatives to fire? Is there evidence that prohibiting fire is contributing to, or subtracting from, conservation interventions? What are the efforts employed to improve fire management in swidden agriculture? Finally, we ask, what commonalities exist between sites? The cases are within the Brazilian Amazon, and are situated along a gradient of human influence from least to most modified they are REDD+ (reduce emissions from deforestation and forest degradation) in the Middle Solimões region, RESEX (sustainable use extractive reserves) in the Arapíuns region, and a Green Municipality Pact (GMP) in Paragominas. Taken together they provide insights concerning the conservation policy and fire context.

\section{STUDY SITES: THREE FOREST CONSERVATION INTERVENTIONS ALONG A GRADIENT OF HUMAN INFLUENCE IN THE BRAZILIAN AMAZON}

We select three forest conservation initiatives each with experience of wildfires and the presence of smallholder farmers, yet distinguished by their context and their approach to achieving sustainable outcomes (Figure 1). The REDD + site operates through payments for environmental services (PES) combined with conditional incentives (Wunder, 2005), RESEX through collective management and secure land rights (Cardoso, 2002), while the GMP operates through subsidy and sanction (Viana et al., 2016).Taken together, these cases offer insights regarding the interplay between conservation and fire policy.

Each of these forest conservation initiatives is home to smallholder communities of ribeirinhos (riverside people), and to a lesser extent, assentados (smallholders settled through agrarian reform). Ribeirinhos are the most numerous rural inhabitants of the Brazilian Amazon, though they are often on the periphery of Brazilian society (Adams et al., 2008). They are of mixed descent (African, Indigenous, Portuguese) (Harris, 2000; Lima, 2005) with diverse livelihoods that include swidden agriculture, fishing, hunting, and forest extraction (Adams et al., 2008; Brondizio, 2004; Brondizio \& Siqueira, 1997; Murrieta \& WinklerPrins, 2003). Assentados may also combine swidden with cattle ranching (Moran, 1993; Schmink \& Wood, 1992). More recently rural Amazonians integrate cash incomes from state welfare packages with their domestic economies (Adams et al., 2008; Steward, 2007).

\section{1 | PES and REDD+: Middle Solimões, Amazonas}

The Mamirauá (decreed 1996, population of 11,532) and Amanã (decreed 1998, population of 3,860) Sustainable Development Reserves in Amazonas form part of the largest area of protected tropical forest on the planet (Queiroz, 2005) and constitute the least deforested site where accidental fires are uncommon, but were recently reported during the drought year of 2015. The two reserves incorporate a similar institutional design to the RESEX yet are integrated into REDD + programmes, introduced in 2011 and 2013 respectively (Steward et al., 2016). REDD+, for which Brazil has been a leading country 


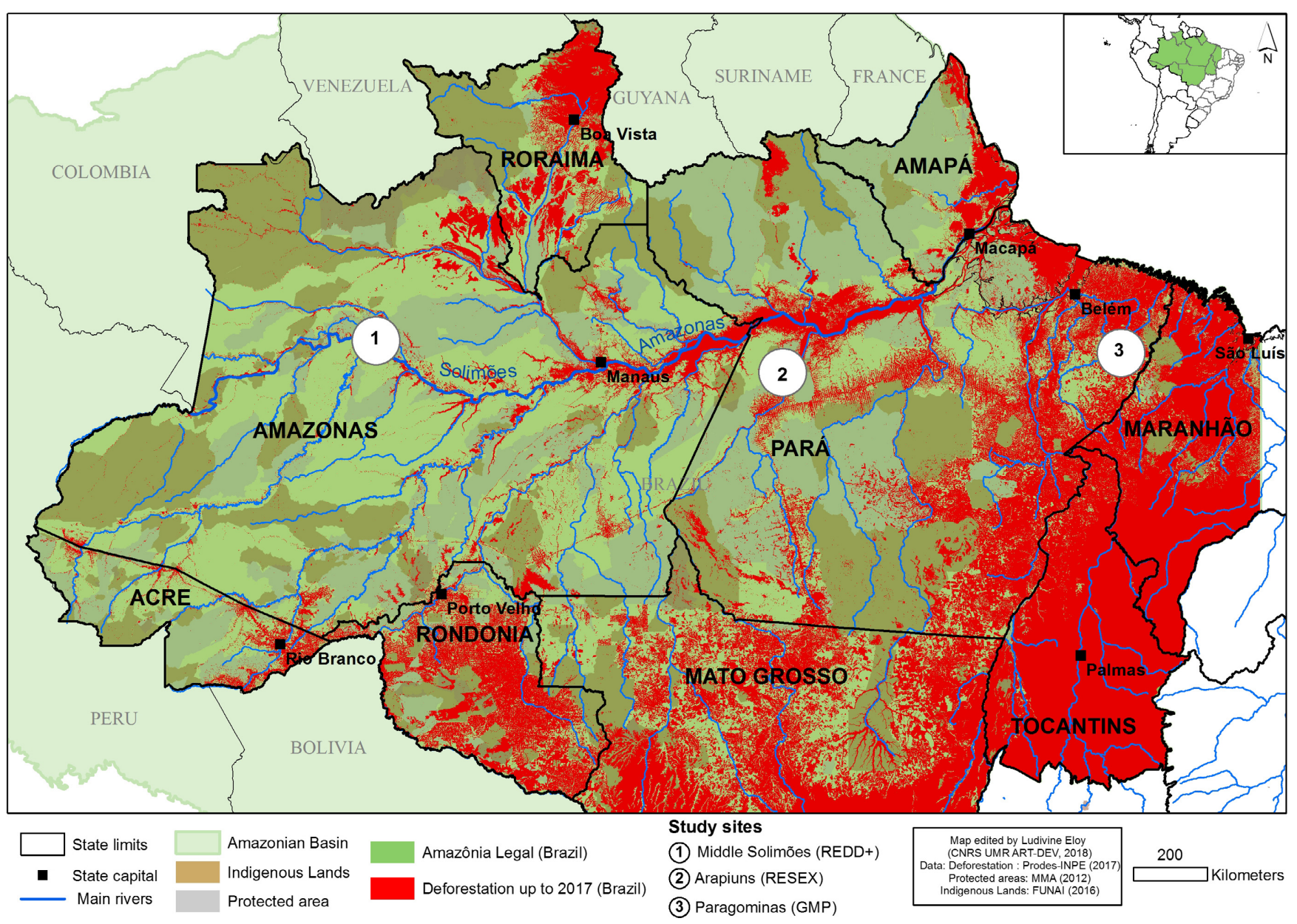

FIGURE 1 Three distinct forest conservation initiative sites across a gradient of deforestation (decreasing from east to west) in the Brazilian Amazon: (1) a reduced emissions from deforestation and degradation (REDD+) site on the Middle Solimões (Amazonas), (2) an extractive reserve (RESEX) along the Arapíuns (Para) and (3) a green municipality pact (GMP) in Paragominas.

since 2004 (Coudel et al., 2015), has been implemented as a forest-carbon PES approach, in which payments provide a conditional incentive for behavioural change and are released on performance (Wunder, 2005).

\subsection{Extractive reserves: Arapíuns site, Pará}

The Tapajós-Arapiuns RESEX, along the Arapíuns river in Pará, was created in 1998. The reserve experienced large-scale $\left(400 \mathrm{~km}^{2}\right.$ ) accidental fires in 1998 (Barlow et al., 2002) and again in 2005 and 2015. The RESEXs are the original model that sought to integrate environmental and socioeconomic imperatives (Cardoso, 2002). RESEX residents are required to use resources in line with regulations specified at the Federal level and as determined via a collective management plan created in partnership with reserve councils and Federal management agencies (i.e., ICMBio). Theoretically, reserves reduce fire through securing land tenure (to avoid repeated cycles of land abandonment), building social capital and collective sustainable resource management (Larson et al., 2008; Persha et al., 2011). Formal land title makes significant welfare allowances (bolsas) available to households (Adams et al., 2008). Additional cash increases access to labour and other resources, that when constrained reduce investments in fire management (Bowman et al., 2008), though may also be related to investments in agriculture and expansion (Phelps et al., 2010).

\section{3 | Green Municipality Pacts in the Brazilian Amazon: Paragominas site, Pará}

Paragominas in Pará state, the least remote, and most disturbed site, has a population of 91,000 (22\% are rural) and from 2010 to 2013 hosted a brigade of six Federal firefighters. However, extensive accidental fires (e.g., 1,700 km ${ }^{2}$ of forest burnt in 2015) are frequent, owing to the large extents of degraded forests and pasture. Pasture and soy agriculture 
dominate the state and 95\% of private land is held by around 500 large landholders. Small-holders (around 6,000 families) are mainly settled on public land relatively far from towns. The GMP was established in 2009 with the goal of zero deforestation (Guimarães et al., 2011) as part of an initiative to counter the blacklisting issued by the Federal government in response to high rates of deforestation (Viana et al., 2016). The landholding elite have the dominant political voice and were the principal advocates of the GMP, pursued mainly through land regularisation, increased monitoring and "green" agribusiness production (Viana et al., 2016).

\section{3 | METHODOLOGY}

Case study sites were selected due to their previous experience with wildfires, the range of human influence they display, the presence of swidden agriculture and their position within a forest conservation intervention. The research questions were cross-cutting across sites (see Introduction). Community meetings were held to introduce the research projects, solicit input from residents and to secure consent to begin research following ethics procedures. A mixed methods approach provided the data for the study, and included collectively two years of observation in the communities, open and semi-structured key stakeholder interviews (these were with community leaders, union leaders and conservation managers), household interviews and questionnaires, participatory mapping and focus group discussions. Communities and households for questionnaire samples were selected at random (GMP, RESEX), or using snowball sampling (REDD+). Participatory meetings addressed issues related to fire management, including collective expectations of intentional fire, the impacts of and solutions to escaped fire, and traditional knowledge of fire management. Household surveys included questions about land management, agricultural practices and extension services, experiences and perceptions of fire policy, fire risk and the utility of fire. Table 1 details the methods applied in each site and the results that follow pertain directly to these site-specific methods. When quotes are presented, pseudonyms are applied. Data analysis was qualitative following thematic analysis, while descriptive statistics helped to quantify the impacts of wildfire in the sites.

TABLE 1 Summary of research methods in the three research sites: the reduced emissions from deforestation and degradation (REDD+) site on the Middle Solimões (Amazonas), the extractive reserve (RESEX) along the Arapíuns river (Pará) and the green municipality pact (GMP) in Paragominas (Pará)

\begin{tabular}{|c|c|c|c|c|}
\hline Site & $\begin{array}{l}\text { Research Method } \\
\text { General approach }\end{array}$ & $\begin{array}{l}\text { Fieldwork } \\
\text { dates }\end{array}$ & $\begin{array}{l}\text { Number of } \\
\text { communities }\end{array}$ & $\begin{array}{l}\text { Number of } \\
\text { questionnaires/interviews }\end{array}$ \\
\hline REDD+ & $\begin{array}{l}\text { Ethnographic observation of } \\
\text { agricultural and burning practices } \\
\text { Semi-structured interviews }\end{array}$ & $02 / 2012-11 / 2014$ & 10 ribeirinho & $\begin{array}{l}90 \text { (general appraisal) } \\
40 \text { (fire specific) }\end{array}$ \\
\hline RESEX & $\begin{array}{l}\text { Focus group discussions } \\
\text { Household questionnaires } \\
\text { Participant observation of } \\
\text { agricultural and burning practices } \\
\text { Participatory mapping of fire escape }\end{array}$ & $06 / 2010-12 / 2010$ & 6 ribeirinho & 83 (fire specific) \\
\hline GMP & $\begin{array}{l}\text { Household questionnaires } \\
\text { Semi-structured interviews } \\
\text { with key stakeholders } \\
\text { Participatory methods (rapid } \\
\text { appraisal, theatre, restitution) }\end{array}$ & $12 / 2012-06 / 2013$ & $\begin{array}{l}4 \text { ribeirinho } \\
12 \text { assentamento }\end{array}$ & $\begin{array}{l}158 \text { (general appraisal) } \\
55 \text { (fire specific) }\end{array}$ \\
\hline
\end{tabular}

\section{4 | RESULTS}

All sites are subject to the regulations specified at the Federal level (e.g., burn licences required by the Forest Act [cf. Carmenta et al., 2011]) and additional policies directed at prohibiting burning particular to their context (Table 2). Each site had a strong narrative against fire largely distributed by external agents and municipal services (radio, TV). In practice, according to interviews with conservation managers (GMP) and surveys with smallholder farmers (RESEX), few sanctions for fire escape had been enacted. 
TA B LE 2 Forest conservation and fire management policies implemented in three forest conservation initiatives in the Brazilian Amazon: the reduced emissions from deforestation and degradation (REDD+) site on the Middle Solimões (Amazonas), the extractive reserve (RESEX) along the Arapíuns river (Pará) and the green municipality pact (GMP) in Paragominas (Pará). Each conservation unit is also subject to the Federal level rules regarding fire (cf. Carmenta et al., 2011)

\begin{tabular}{|c|c|c|c|}
\hline & REDD ${ }^{\mathbf{a}}$ & RESEX & GMP \\
\hline $\begin{array}{l}\text { Forest Conservation } \\
\text { Initiative (FCI) }\end{array}$ & $\begin{array}{l}\text { - No agriculture in primary forests } \\
\text { Rewards for zero deforestation } \\
\text { (Forest Conservation Allowance } \\
\text { Program [FCAP]) }\end{array}$ & $\begin{array}{l}\text { - Management plan for sustainable } \\
\text { resource use } \\
\text { - No agriculture in primary } \\
\text { forests } \\
\text { - Secure land rights }\end{array}$ & $\begin{array}{l}\text { - Zero-deforestation pact to exit } \\
\text { Federal blacklist } \\
\text { - Land regularisation and } \\
\text { monitoring }\end{array}$ \\
\hline $\begin{array}{l}\text { Fire Management } \\
\text { Policy (FMP) }\end{array}$ & $\begin{array}{l}\text { - Promotes fire-free agroforestry (FCAP) } \\
\text { Restricts finance to projects } \\
\text { based on fire-free swidden farming }\end{array}$ & $\begin{array}{l}\text { Burning to follow management } \\
\text { plan } \\
\text { - Restricts plot size }\end{array}$ & $\begin{array}{l}\text { Municipal law (Law 765/2011) } \\
\text { prohibits all fire use and ascribes } \\
\text { sanctions (provides for sanctions, } \\
\text { but never applied to smallholders) }\end{array}$ \\
\hline $\begin{array}{l}\text { Implementation of } \\
\text { FCI and FMP }\end{array}$ & $\begin{array}{l}\text { BioRec trains farmers (45 in first } \\
\text { cycle) in agroforestry using } \\
\text { demonstration areas (8) in first cycle }\end{array}$ & $\begin{array}{l}\text { - Sustainable livelihood } \\
\text { initiatives } \\
\text { - Awareness raising regarding } \\
\text { "good fire management" }\end{array}$ & $\begin{array}{l}\text { - Municipality subsidises } 12 \text { tractors } \\
\text { to till land } \\
\text { - PrevFogo brigades during burning } \\
\text { season to do awareness raising } \\
\text { - Subsidises dairy farming through } \\
\text { credit and extension }\end{array}$ \\
\hline
\end{tabular}

${ }^{a}$ The Forest Conservation Allowance Programme and the BioRec Project.

\section{1 | Frequency of accidental fires confirms policy failure}

In all sites, even following policy implementation, damages reported in surveys (e.g., to forests and livelihoods) had accrued from escaped fires, demonstrating that neither fire management policies nor forest conservation initiatives are mitigating wildfires (Table 3). In the least disturbed REDD+ site, losses of mature agroforestry systems had occurred following the first escaped fires in the area, which were considered to be related to recent extreme drought events. In the RESEX, over a third of households had experienced accidental fires and associated burdens which included lost crops, forest degradation and poor hunting; and over a third of the households believed fire threatened their homes and land. Residents perceived the awareness raising related to the illegality of fire explained a positive shift towards better fire management. However, accidental fires have since returned to the region (Globo, 2017). In the GMP, around 50\% of households had at least two fire accidents in their property in the past five years, and over two-thirds incurred damage exceeding 2,000 R\$ (Cammelli, 2014). Following the fire ban, small-holders continued to consider fire a threat to their property, mainly advancing from surrounding large properties (interviews and focus groups).

TA B LE 3 Smallholder farming system and experience of escaped fires across three forest conservation initiatives in the Brazilian Amazon: the reduced emissions from deforestation and degradation (REDD+) site on the Middle Solimões (Amazonas), the extractive reserve (RESEX) along the Arapíuns river (Pará) and the green municipality pact (GMP) in Paragominas (Pará)

\begin{tabular}{|c|c|c|c|}
\hline & REDD+ & RESEX & GMP \\
\hline Property rights & Communal & Communal & Private \\
\hline Size (ha) & $3,474,000$ & 677,513 & $1,934,200$ \\
\hline Use fire for their annual cultures (\% farming households $[\mathrm{FH}]$ ) & 100 & 100 & 75 \\
\hline Used tractor at least once $(\% \mathrm{FH})$ & 0 & 0 & 45 \\
\hline Fire risk impacts production practice choices $(\% \mathrm{FH})$ & ND & 10 & 40 \\
\hline Experienced accidental fire in the last five years (\% FH) & ND & 42 & $48>\times 2$ \\
\hline Report fire damages at the household level (\% FH) & ND & 62 & $70(>2,000 \mathrm{R} \$)$ \\
\hline
\end{tabular}




\subsection{Centrality of fire to smallholder agriculture, identity and social practice}

In all sites, swidden agriculture was a significant element of cultural identity, enabling autonomous production and yet appeared under threat, from anti-fire rhetoric. In all sites, qualitative results highlighted numerous expressions of the cultural importance of fire-based swidden, including individuals admiring the agricultural work of their neighbours, showing pride in the bounty of their efforts and referring to planted land as "beautiful". Fire was valued as a tool to maintain, clean and improve agricultural and living areas. The independence swidden afforded smallholders was referred to as an endogenous form of (non-monetary) wealth, necessary in a context of limited state support. Social reproduction was integrated with the swidden process and parents encouraged even young children to contribute labour to agricultural work in the fields and thereby obtain the essential skills to practice swidden. Reciprocal work parties to prepare, sow and harvest fields were important social events that contributed to strengthen family and community ties.

Particularly in the GMP and REDD+ sites, interviews with farmer leaders showed that the cultural familiarity with fire and the independence that it enabled was jeopardised by the awareness-training raising regarding the illegality of fire (e.g., via radio and in rural workers union meetings). In all sites a sense of constant surveillance (e.g., expressed through awareness of satellite observation) was contributing to a new uneasiness in a previously autonomous space of agricultural decision-making: "we know that they [REDD+ coordinators] are watching us by satellite and can see all clearings we make in the forest" (Seu Geraldo, REDD+).

\subsection{Criminalising fire and the negative legacy of interventions undermines FCI partnerships}

According to practitioners and reserve residents, the implementation of REDD + in the study sites lacked the transparency of previous conservation initiatives in the area and relied less on alliances between practitioners and farmers. In the REDD+ site, swidden practices, including burning, were portrayed as environmentally destructive. The REDD + narrative attached a stigma to burning, for example through the promise of benefits conditional on switching from fire-based agriculture. This created a context in which farmers became cautious about their fire use.

In the RESEX and GMP sites restrictions on fire use were commonly acknowledged as being part of a broader narrative and norm of policies that are neither supportive nor cognisant of rural Amazonian realities and contexts. In interviews and focus groups, farmers spoke about being "half forgotten" in relation to their "condition" (their capacity) and felt dismissed by outsiders who were seen either to draft policies that are unrealistic to follow, or to arrive with interventions misaligned to local realities. In the GMP site, farmers considered that the zero-fire initiative and municipal law banning fire directly ignored their dependence on fire in agricultural practices and emphasised the divide between the municipal "elite" and the rural farmers. Although farmers were genuinely preoccupied with the increase of wildfires and associated burdens, they felt no obligation to stop agricultural fires in order to "serve" a political project that did not respond to their livelihood needs: "we are half forgotten here, those that make the rules sit in their offices in Brasilia and don't know the conditions of the rural worker" (Seu Careca, RESEX).

In the RESEX, restrictions on swidden plot sizes and locations were introduced in 2010 along with increased monitoring. In focus groups and participant observation, residents voiced their fear of being fined and that burning restrictions had confined their farming choices. While establishment of the reserve represented a victory for the residents, the burden of these new regulations and the subsequent livelihood restrictions were considered a cost. The lack of engagement to solicit farmers' inputs and expertise was recognised by community members as a major factor contributing to project failure and a key driver leading to a general scepticism of the potential of interventions introduced by external agents. A similar situation occurred in the REDD+ site, where frustrations related to socio-economic development initiatives were associated with projects not being in line with regional ecologies, local realities and infrastructure.

\subsection{Restricting fire in the absence of alternatives}

Although residents in all sites expressed interest in alternatives to fire, in practice access to fire-free agriculture was extremely limited. Across sites, even where external support was greatest (i.e., GMP) the majority of farmers (75\%) relied exclusively on fire to establish their annual crops (Table 3).

In the REDD+ site, only two of eight farmers responsible for experimental demonstration areas continued to manage their agroforests after technicians withdrew following training activities. Further, the high labour requirements of fire-free agriculture (i.e., to organise large working groups to clear land manually) were perceived as prohibitive compared with burning (which requires as few as one person). 
In surveys, RESEX residents $(>67 \%)$ stated that they knew of few reasonable alternatives to fire for agricultural purposes (i.e., given financial, technological and expertise constraints). The most frequently mentioned alternatives were "direct planting" (manual or mechanised land clearance), perennial crops and timber extraction. In the RESEX, community members experiencing externally driven attempts at developing fire-free livelihoods (e.g., through installation of a carpentry workshop) were debilitated by bureaucratic procedures (e.g., the protracted process of acquiring permits for sustainable harvest within an FCI), or by external agents backing activities ill-suited to the local ecology (e.g., equipment to extract oil from species that do not occur locally). Nobody in the communities had experience of a tractor or "direct planting" (Table 3).

In the GMP, interviews showed that paradoxically those with experience of state-supported tractors tended to reject them as a viable alternative because their use induced harvest failures (since other necessary inputs, such as lime and fertilisers, were not available). Further, the municipality-provided tractors were only able to till pre-cleared land while farmers preferred tractors capable of felling mature vegetation. Even farmers with access to private tractors continued to utilise fire to clear vegetation and provide initial fertilisation and recognized that access was limited:

They say the smallholder shouldn't deforest, that agriculture needs to change, without fire, but until today I ask myself, how will we do this? We have a tractor, between 1,000 families, if each family takes one day, even in three years we won’t have finished. (Seu Zé, GMP)

Dairy production in the GMP was supported, but in interviews policy-makers recognised that few farming households $(<50)$ benefited and farmers still deemed fire use essential for pasture renewal and for manioc cultivation in swidden. Surveys showed that cultivating perennials was practiced by around $10 \%$ of farmers, and $40 \%$ of respondents would switch to perennials if fire risk declined. The PrevFogo brigade promoted fire-free options, and initiated two agro-ecological demonstration units, however both were observed to be abandoned after the brigades withdrew (in 2013).

\section{5 | Fire management training to mitigate escaped fires}

At all sites, externally driven policies appeared to leave little space for endogenous solutions and collaboration between stakeholders. Adaptation was circumvented through restriction, rather than encouraged; much less supported. Training in fire management was uncommon and restricted to the GMP site.

In the RESEX, awareness-raising regarding "good" fire management had been driven mostly through the radio and the rural workers union. However, the advice given in these communication campaigns focused on using fire breaks, which farmers routinely regarded as an unsuitable option. In surveys and observations farmers stated that the labour requirements to clear a circumference around the plot were prohibitive and a general opinion that embers are carried on the wind made farmers sceptical of the performance of fire breaks. In the GMP, community leaders contended that it would be more efficient for the municipality to provide tractors to enable construction of wide fire breaks to prevent wildfires instead of those for tilling the land.

Combatting escaped fires was often considered a main challenge, and in the GMP fire-fighting was discussed in community meetings (interviews showed that $>60 \%$ of respondents had been to meetings about fire). Moreover, fire restriction policy itself generated perverse outcomes, as Federal activities (e.g., PrevFogo) were legally prohibited from supporting improvements to fire management because intentional fire is illegal. PrevFogo was under-equipped to combat escaped fires (e.g., no water tanks) and fire-fighting actions depended on community mobilisation which prioritized protecting the houses, not saving the fields.

In the RESEX, the head of the rural farmers union was guardian of a cache of equipment for fire combat, but these were chronically inferior (e.g., fire beaters with rotten handles, small water-retaining backpacks) and too few - given the size of the reserve and the dispersed nature of the communities and agricultural plots (Figure 2). Community leaders stated that collective action had been employed to combat the fires of 2005, when households worked together carrying water and soaking their homes for protection. Yet, given the size of the area and the volume of fuel, this was not sufficient to contain the blaze. State-based support to combat conflagrations was not reported by community leaders or local managers.

Given the difficulties of combatting wildfires, farmers interviewed at the GMP and RESEX sites aspired to improve fire management through community-level organisation. In focus groups, residents also considered externally led awareness raising, monitoring and training workshops as essential components of a successful intervention. However, formal collaborative discussions on safe use of fire were almost entirely absent across all sites. 


\subsection{Common lessons for fire mitigation across forest conservation initiatives}

The REDD+ initiative placed emphasis on signing up beneficiaries and distributing income and material benefits after their participation in agricultural training workshops. Little or no investment was made in monitoring activities to assess participants' practices after fire-free training, or to ensure the conditional element of the reward. Recommendations announced in the training workshops were not matched with investments to equip farmers with the skills needed to modify their practices. The continued use of primary forest for swidden indicates the intervention has not motivated fire-free practices.

In the RESEX people expressed their conviction that secure tenure safeguards the forest (and their access to it) because new claimants and industrial scale extraction are prohibited. However, the land rights granted with the RESEX were understood to be limited and people were unclear about what would happen when the title expires. Further, the prevailing necessity for harmonious community relations contributed to an acceptance of transgressors of rules. While people complained about careless burning they also stated that there was little they could do to reprimand those responsible, since they must live together. When agents of the Federal Environment department made patrols (e.g., for trading game and timber), residents spread the word and hid items that might be confiscated. Prohibition induced farmers to become reluctant to speak due to a context of fear and instead conceal their actions, their needs and limitations.

The GMP did not manage to shift behaviour through subsidies or through sanctions. The sanctions were not administered since agents recognised the unfeasibility of fining already marginalised land user groups. The subsidy and support element of the GMP was unable to secure meaningful impact and appeared largely tokenistic because only a few farmers benefited and, as discussed above, those that did identified weaknesses in the design which was founded on agro-business models. Further, the prohibition on fire severed the dialogue between farmers and municipal agents, since finding ways to manage fire safely could not be discussed, which created a context of suspicion.

\section{5 | DISCUSSION}

Across all of the sites, escaped fire (wildfire) represented a socio-environmental burden undermining both the conservation and development goals of the conservation initiatives. Increasing instances of wildfires suggest that contemporary restrictive policy solutions to fire are failing. The conservation initiatives and fire policies exemplify the policy-practice gap inherent in many conservation efforts (Toomey et al., 2016), and in tropical fire management (Kull, 2004; Mathews, 2005). Across the tropics, and within conservation initiatives that permit sustainable use, smallholders depend on firebased agriculture (Dressler et al., 2016; VanVliet et al., 2013). The failure of restrictive fire policy indicates that improvements are needed to enhance both environmental and social outcomes in conservation initiatives.

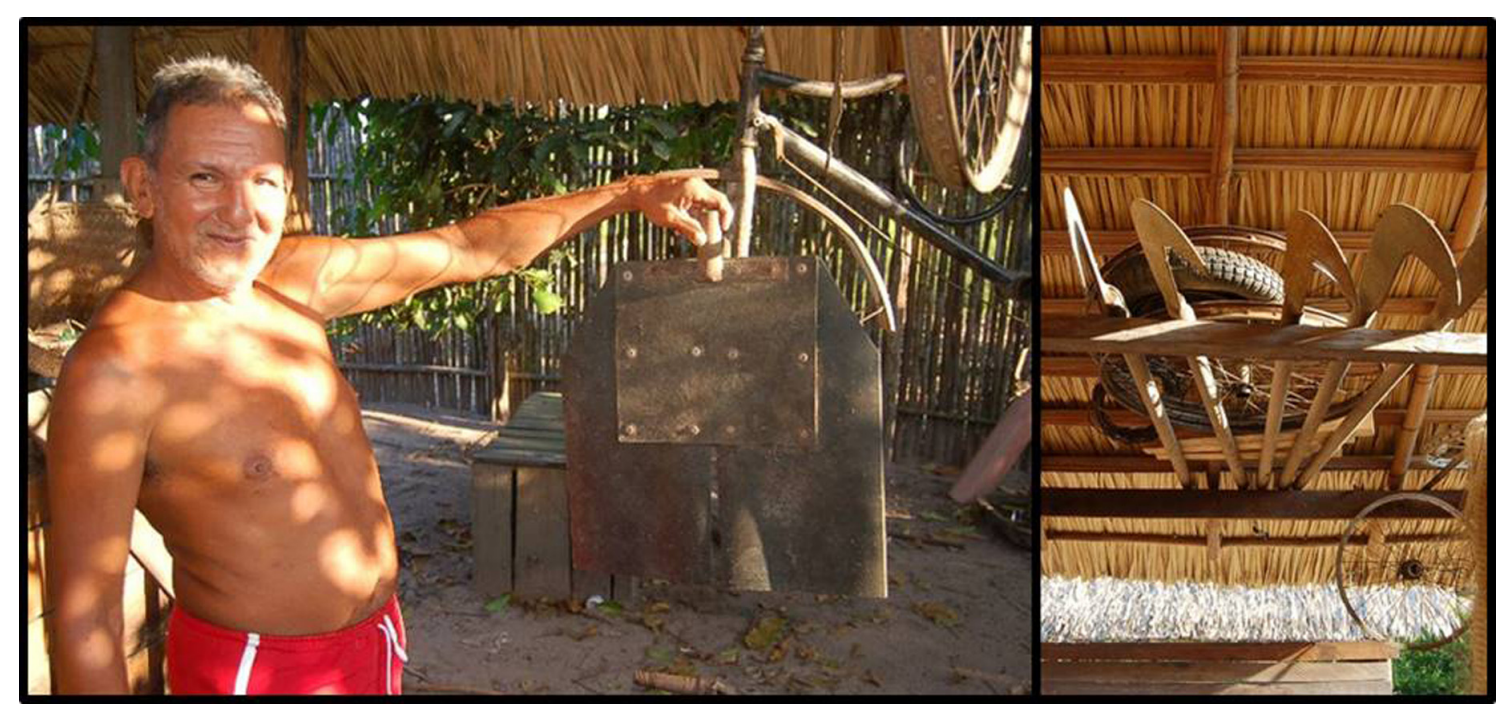

F IG URE 2 The rural workers union president holds the chronically inadequate supply of fire-fighting equipment that serves all communities in the RESEX (Pará) and additional communities outside of the reserve. 


\section{1 | Criminalising fire: Creating risky conditions for conflagrations in conservation areas}

We show that conservation initiatives were compromised by the combination of fire dependence and a lack of discussion on how to manage fire safely. Both conservation initiatives and fire policies criminalise practices that remain indispensable to small-holders and thereby propagate a context in which intentional fire becomes illicit practice (Kull, 2004; Mathews, 2005). Through fuelling a taboo surrounding fire, the space for dialogue aimed at identifying and defining ways forward is closed and the gap between conservation practitioners, reserve managers, implementation agents and farmers is widened (McDaniel et al., 2005). Such an approach may perversely increase fire risk by inducing smallholders to burn in secret, or to abandon rather than invigilate the burn for fear of sanction (Kull, 2004); and through not supporting adapting techniques and management practices that could mitigate fire escape. This is perhaps particularly problematic in the context of increasingly flammable forests and extended fire weather seasons (Jolly et al., 2015). Further, the importance of incorporating the human dimension in forest conservation initiatives has been acknowledged (Bennett, 2016) and strengthening community alliances is deemed crucial to the future conservation of forests (Brosius \& Russell, 2003; Queiroz \& Peralta, 2006).

Our sites highlight the weakness of policy development responses to natural resource challenges that are elaborated without local participation (Toomey et al., 2016). Implementation is undermined by a process that introduces with potentially external agents with pre-determined agendas, and little local knowledge or awareness of local capacity and constraints. Further, in some cases, those implementation agents that do not engage with local realities may be reluctant to enforce starkly misaligned external policy prescriptions, and institutional structures themselves may need adapting to enable feedback and improvements (Mathews, 2005; Vasan, 2002). The risk of negative legacy of past interventions is considerable and puts additional pressure (through degrading positive perceptions) on defining ways forward collectively (Bennett, 2016). Engaging with local realities, subjectivities, knowledges and priorities might capture opportunities for solutions that are tenable and that mitigate escaped fires and the associated social and environmental burdens they entail (Bennett, 2016; Biggs et al., 2011). Working towards management that pivots on discussion, deliberation and participation in a multi-way dialogue could provide a better context for identifying solutions to fire escape by mutual agreement (Carmenta et al., 2013; Toomey et al., 2016).

To date, adaptive fire management strategies have encountered some success, but focus almost exclusively on firedependent biomes, such as grasslands and savannas (Sletto \& Rodriguez, 2013). The potential merits of a fire management approach allowing for fire use has not yet been evaluated in the tropical forest landscapes of the Brazilian Amazon.

\section{2 | Equity dimensions of restrictive fire policy}

Smallholders are being criminalised for methods which previously have proven relatively benign (RibeiroFilho et al., 2013). Fire management has been practised for generations but new forest ecologies (e.g., fragmented and degraded) and new climatic contexts necessitate new know-how (Emperaire \& Eloy, 2015). The distributional justice of restricting burning by fire-dependent smallholders, shifting the burden of increasingly flammable landscapes (e.g., through fragmentation or climate change) on to smallholders who themselves have no access to alternatives, requires scrutiny (Sorrensen, 2009). Implementing fire suppression policies without regard to environmental and social complexities propagates the policy practice gap, supports the power of the state and normalises the narrative of international conservation agendas (Brosius et al., 2003; Kull, 2004; Mathews, 2005). Importantly, prohibiting fire without providing alternatives may create additional burdens for smallholders, including food insecurity and cultural dilution.

\section{3 | Ways forward: Transcending the taboo of fire}

Fire management is integral to all forest conservation in swidden contexts and it is therefore imperative to address how previously benign traditional practices (RibeiroFilho et al., 2013) can be modified to suit new challenges. A more nuanced discussion of alternatives, potentially including modified forms of fire use grounded in local realities, may be needed if fire escape is to be averted and the sustainability of conservation initiatives enhanced. To enable the emergence of innovative solutions adapted to local conditions, policies must aim at creating spaces for social learning, where new perceptions can emerge, new knowledge can be constructed, and new social interactions defined (Coudel et al., 2017; Röling et al., 2002). Such learning goes beyond a top-down approach of informing to achieve compliance with external rules; it must promote a constructive process of exchange of viewpoints in which stakeholders perceive a need to engage in change (Marshall \& Marshall, 2007).

The wildfire mitigation strategies and policy combinations at all sites have underperformed, which suggests weaknesses in design. While the RESEX model is expected to engender behavioural change through shifting incentives via securing 
land tenure, in practice, residents were concerned about the capped temporal availability of these rights, were unable to sanction neighbours, and did not benefit from alternative livelihood initiatives. In the REDD + site, nuance was lacking in favour of blanket restrictive approaches, the conditionality of the reward was not met, and instead recipients continued regular farming methods albeit more covertly. In the GMP site, sanctions were not issued, subsidies were very limited, and smallholders felt detached from the goals of the programme.

However, the introduction of conservation initiatives has motivated continued organisation and access to resources (including rewards, subsidies and land rights) that could potentially be tapped to enhance a dialogue surrounding improved fire management. Our results build on a body of previous work that highlights the need for transparent approaches to navigate difficult trade-offs, and to recognise "wicked-challenges" and the significance of champions (Game et al., 2014). Indeed, farmers attested to the attraction of community-level engagement and influence in programme design.

Pre-emptive actions are likely to be the best way forward since capacity to combat escaped fires is extremely limited, particularly in remote regions such as the REDD + and RESEX sites presented here. Fire management interventions, if explored, would need external support and should be targeted to the specific ecological conditions of the site, which can be identified in partnerships with local farmers. Interventions will need to be monitored and evaluated to inform an evidence base that can support decisions for improved approaches (Morello et al., 2017; Nobre et al., 2016). Innovative ways of communicating climate forecasts to smallholders would enable burning practices to be aligned accordingly (Moran et al., 2006).

\section{6 | CONCLUSIONS}

We recognise the risk wildfires pose to social and environmental conditions across the tropics and within forest conservation initiatives. We assert that the contemporary prevalence of restrictive fire policies that criminalise already marginalised smallholders do not adequately mitigate these risks. Rather, current fire management policy is undermining conservation initiatives, creating a tangible need to move beyond forbidden fire towards identifying approaches that outperform this model for forests and livelihoods. Our results suggest that given the absence of imminent and viable fire-free alternatives, a new model of fire management in sites where swidden and conservation collide warrants experimentation. While we cannot state which solutions would be most effective, we suggest that exploring options that move beyond forbidden fire may in fact serve to reduce fire risk, increase the legitimacy of local level interventions, enable farmers to practice small-scale agriculture, maintain their cultural identity and retain their food security, and subsequently meet the environmental and social imperatives of forest conservation.

\section{ACKNOWLEDGEMENTS}

The authors would like to thank the following researchers for the rich discussions we had around the fire issue: Lívia Navegantes (UFPA), Joice Ferreira (Embrapa), Marie-Gabrielle Piketty (CIRAD), Federico Cammelli (NMBU), and Luiza Câmpera and Camila Verbicaro for the additional support in data collection. The logistical support of Mamirauá Institute for Sustainable Development (MCTIC), ICMBio, Tapajoara and the communities in the field sites enabled the work and we are grateful. The authors are grateful for the insightful comments given by two anonymous reviewers.

\section{OR CID}

Rachel Carmenta (D) http://orcid.org/0000-0001-8607-4147

\section{REFERENCES}

Adams, C., Murrieta, R., Neves, W., \& Harris, M. (Eds.) (2008). Amazon peasant societies in a changing environment: Political ecology, invisibility and modernity in the rainforest. Berlin, Germany: Springer.

Alencar, A. A., Brando, P. M., Asner, G. P., \& Putz, F. E. (2015). Landscape fragmentation, severe drought, and the new Amazon forest fire regime. Ecological Applications, 25, 1493-1505.

Aragão, L., \& Shimabukuro, Y. (2010). The incidence of fire in Amazonian forests with implications for REDD. Science, 328, 1275-1278.

Assunção, J., Gandour, C., \& Rocha, R. (2015). Deforestation slowdown in the Brazilian Amazon: Prices or policies? Environment and Development Economics, 20, 697-722. 
Barlow, J., Haugaasen, T., \& Peres, C. A. (2002). Effects of ground fires on understorey bird assemblages in Amazonian forests. Biological Conservation, 105, 157-169.

Barlow, J., Lennox, G., Ferreira, J., Berenguer, E., Lees, A., Nally, R., \& Gardner, T. A. (2016). Anthropogenic disturbance in tropical forests can double biodiversity loss from deforestation. Nature, 535, 144.

Barlow, J., Parry, L., Gardner, T. A., Ferreira, J., Aragao, L. E. O. C., Carmenta, R., \& Cochrane, M. A. (2012). The critical importance of considering fire in REDD+ programs. Biological Conservation, 154, 1-8.

Bennett, N. J. (2016). Using perceptions as evidence to improve conservation and environmental management. Conservation Biology, 30, 582592.

Biggs, D., Abel, N., Knight, A. T., Leitch, A., Langston, A., \& Ban, N. (2011). The implementation crisis in conservation planning: Could “mental models" help? Conservation Letters, 43, 169-183.

Bowman, M. S., Amacher, G. S., \& Merry, F. D. (2008). Fire use and prevention by traditional households in the Brazilian Amazon. Ecological Economics, 67, 117-130.

Brondizio, E. S. (2004). Agriculture intensification, economic identity, and shared invisibility in amazonian peasantry: Caboclos and colonists in comparative perspective. Culture \& Agriculture, 26, 1-24.

Brondizio, E. S., \& Siqueira, A. (1997). From extractivists to forest farmers: Changing concepts of cabaclo agroforestry in the Amazon estuary. In B. L. Isaac (Ed.), Research in economic anthropology (Vol. 18, pp. 233-279). London, UK: JAI Press Int.

Brosius, J. P., \& Russell, D. (2003). Conservation from above: An anthropological perspective on transboundary protected areas and ecoregional planning. In U. Goodale, M. , M. Stern, J., C. Margoluis, A. Lanfer, G. \& M. Fladeland (Eds.), Transboundary protected areas: The viability of regional conservation strategies (pp. 39-66). New York, NY: Food Products Press.

Bruner, A. G., Gullison, R. E., Rice, R. E., \& da Fonseca, G. A. B. (2001). Effectiveness of parks in protecting tropical biodiversity. Science, $291,125-128$.

Cammelli, F. (2014). Smallholders' collective action and fire risk in the Brazilian Amazon. Università degli Studi di Firenze, Masters in Economy.

Cardoso, C. (2002). Extractive reserves in Brazilian Amazonia: Local resource management and the global political economy. Aldershot, UK: Ashgate publishing.

Cardoso, M. F., Hurtt, G. C., Moore, B., Nobre, C. A., \& Prins, E. M. (2003). Projecting future fire activity in Amazonia. Global Change Biology, 9, 656-669.

Carmenta, R., Blackburn, A., Davies, G., de Sassi, C., Lima, A., Parry, L., \& Barlow, J. (2016). Does the establishment of sustainable use reserves affect fire management in the humid tropics? PLOS ONE, 11, e0149292.

Carmenta, R., Parry, L., Blackburn, A., Vermeylen, S., \& Barlow, J. (2011). Understanding human-fire interactions in tropical forest regions: A case for interdisciplinary research across the natural and social sciences. Ecology and Society, 16, 53.

Carmenta, R., Vermeylen, S., Parry, L., \& Barlow, J. (2013). Shifting cultivation and fire policy: Insights from the Brazilian Amazon [journal article]. Human Ecology, 41, 603-614.

Carmenta, R., Zabala, A., Daeli, W., \& Phelps, J. (2017). Perceptions across scales of governance and the Indonesian peatland fires. Global Environmental Change, 46, 50-59.

Carvalheiro, K. (2004). Community fire management in the Marana region, Brazilian Amazonia. Gainesville, FL: Master of Arts, University of Florida.

Carvalho, E., Mello, R., Souza, M. L., \& Silva, L. A. (2009). Técnicas de prevenção de fogo acidental: Método bom manejo de fogo para áreas de agricultura familiar. In IPAM (Ed.), Belem, Brazil: IPAM - Instituto de Pesquisa Ambiental da Amazônia.

Cochrane, M. A., \& Barber, C. P. (2009). Climate change, human land use and future fires in the Amazon. Global Change Biology, 15, 601-612.

Costa, L. M. (2006). Comunicação e Meio ambiente: A analise das campanhas de prevenção a incêndios florestais na Amazônia. Belém, Brasil: Prêmio NAEA.

Costanza, R., Groot, R. d., Sutton, P., van der Ploe, S., Anderson, S., Kubiszewski, I., Farber, S., \& Turner, R. K. (2014). Changes in the global value of ecosystem services. Global Environmental Change, 26, 152-158.

Coudel, E., Ferreira, J., de Carvalho Amazonas, M., Eloy, L., Hercowitz, M., Mattos, L., May, P., Muradian, R., Piketty, M.-G., \& Toni, F. (2015). The rise of PES in Brazil: From pilot projects to public policies. Handbook of Ecological Economics, 18, 450-472.

Coudel, E., Tonneau, J.-P., Bousquet, F., Caniello, M., Chia, E., Daré, W., Gurung, T. R., Jankowski, F., Leal, F., Le Page, C., Piraux, M., ReyValette, H., Sabourin, E., \& Trébuil, G. (2017). Social learning for territorial development. In P. Caron, E. Valette, T. Wassenaar, G. Coppens d'Eeckenbrugge \& V. Papazian (Eds.), Living territories to transform the world (pp. 157-162). Versailles, France: CIRAD.

de Mendonça, M. J. C., Diaz, M. D. V., Nepstad, D., da Motta, R. S., Alencar, A., Gomes, J. C., \& Ortiz, R. A. (2004). The economic cost of the use of fire in the Amazon. Ecological Economics, 49, 89-105.

Denevan, W. M., \& Padoch, C. (1987). Swidden-fallow agroforestry in the Peruvian Amazon. Advances in Economic Botany, 5, 91-106.

Denich, M., Vielhauer, K., Kato, M., Block, A., Kato, O. R., Sa, T., Lücke, W., \& Vlek, P. L. G. (2004). Mechanized land preparation in forestbased fallow systems: The experience from Eastern Amazonia. Agroforestry Systems, 61-2, 91-106.

Dressler, W. H., Wilson, D., Clendenning, J., Cramb, R., Keenan, R., Mahanty, S., Bruun, T. B., Mertz, O., \& Lasco, R. D. (2016). The impact of swidden decline on livelihoods and ecosystem services in Southeast Asia: A review of the evidence from 1990 to 2015. Ambio, 46, 291310.

Eloy, L., Bilbao, B., Mistry, J., \& Schmidt, I. B. (2018). From fire suppression to fire management: Advances and resistances to changes in fire policy in the savannas of Brazil and Venezuela. The Geographical Journal. Advance online publication. https://doi.org/10.1111/geoj.12245 
Emperaire, L., \& Eloy, L. (2015). Amerindian agriculture in an urbanising Amazonia (Rio Negro, Brazil). Bulletin of Latin American Research, $34,70-84$.

Engel, S., Pagiola, S., \& Wunder, S. (2008). Designing payments for environmental services in theory and practice: An overview of the issues. Ecological economics, 65, 663-674.

Ferraro, P. J., \& Hanauer, M. M. (2014). Advances in measuring the environmental and social impacts of environmental programs. Annual Review of Environment and Resources, 39, 495-517.

Friess, D. A., Phelps, J., Garmendia, E., \& Gómez-Baggethun, E. (2015). Payments for Ecosystem Services (PES) in the face of external biophysical stressors. Global Environmental Change, 30, 31-42.

Game, E. T., Meijaard, E., Sheil, D., \& McDonald-Madden, E. (2014). Conservation in a wicked complex world; challenges and solutions. Conservation Letters, 7, 271-277.

Gatti, L. V., Gloor, M., Miller, J. B., Doughty, C. E., Malhi, Y., Domingues, L. G., \& Lloyd, J. (2014). Drought sensitivity of Amazonian carbon balance revealed by atmospheric measurements. Nature, 506, 76.

Gaveau, D. L. A., Pirard, R., Salim, M., Tonoto, P., Yaen, H., Parks, S., \& Carmenta, R. (2017). Overlapping land claims limit the use of satellites to monitor no-deforestation commitments and no-burning compliance. Conservation Letters, 10, 257-264.

Gebara, M., \& Agrawal, A. (2017). Beyond rewards and punishments in the Brazilian Amazon: Practical implications of the REDD+ discourse. Forests, 8, 66.

German, L. (2010). Local knowledge and scientific perceptions: Questions of validity in environmental knowledge. In L. German, J. Ramisch, \& R. Verma (Eds.), Beyond the biophysical: Knowledge, culture, and power in agriculture and natural resource management (p. 301). Dordrecht, The Netherlands: Springer.

Globo (2017). Incêndio em área de reserva florestal no Pará é controlado; local segue monitorado, Globo. Retrieved from https://g1.globo.com/ $\mathrm{pa} /$ santarem-regiao/noticia/incendio-em-area-de-reserva-florestal-no-para-e-controlado-local-segue-monitorado.ghtml

Guimarães, J., Veríssimo, A., Amaral, P., \& Demachki, A. (2011). Municípios Verdes: Caminhos para a sustentabilidade. Belém, PA: Imazon.

Hardesty, J., Myers, R., \& Fulks, W. (2005). Fire, ecosystems and people: Threats and strategies for global biodiversity conservation. GFI Technical Report. 2007-2. The Nature Conservancy, Arlington, VA.

Harris, M. (2000). Life on the Amazon: The anthropology of a Brazilian peasant village. London, UK: Oxford University Press.

Harwell, E. E. (2000). Remote sensibilities: Discourses of technology and the making of Indonesia's natural disaster. Development and Change, 31, 307-340.

Jolly, W. M., Cochrane, M. A., Freeborn, P. H., Holden, Z. A., Brown, T. J., Williamson, G. J., \& Bowman, D. M. (2015). Climate-induced variations in global wildfire danger from 1979 to 2013. Nature Communications, 6, 7537.

Joppa, L. N., Loarie, S. R., \& Pimm, S. L. (2008). On the protection of "protected areas". Proceedings of the National Academy of Sciences of the United States of America, 105, 6673-6678.

Joslin, A. H., Markewitz, D., Morris, L. A., Oliveira, F. D., Figueiredo, R. O., \& Kato, O. R. (2011). Five native tree species and manioc under slash-and-mulch agroforestry in the eastern Amazon of Brazil: Plant growth and soil responses. Agroforestry Systems, 81, 1-14.

Kull, C. A. (2002). Madagascar's burning issue: The persistent conflict over fire. Environment, 44, 8-19.

Kull, C. A. (2004). Isle of fire: The political ecology of landscape burning in Madagascar. Chicago: University of Chicago Press.

Larson, A., Cronkleton, P., Barry, D., \& Pacheco, P. (2008). Tenure rights and beyond: Community access to forest resources in Latin America. Occasional Paper. Bogor, Indonesia: CIFOR.

Lima, D. D. M. (2005). Diversidade socioambiental nas várzeas dos rios Amazonas e Solimões: Perspectivas para o desenvolvimento da sustentabilidade. In D. D. M. Lima (Ed.), Projeto Manejo dos Recursos Naturais da Várzea. Manaus, Brazil: IBAMA/ProVárzea.

Marshall, N. A., \& Marshall, P. A. (2007). Conceptualising and operationalising social resilience within commercial fisheries in northern Australia. Ecology and Society, 12.

Mathews, A. S. (2005). Power/knowledge, power/ignorance: Forest fires and the state in Mexico. [Article]. Human Ecology, 33, 795-820.

McDaniel, J., Kennard, D., \& Fuentes, A. (2005). Smokey the Tapir: Traditional fire knowledge and fire prevention campaigns in lowland Bolivia. Society \& Natural Resources, 18, 921-931.

Mistry, J. (1998). Decision-making for fire use among farmers in savannas: An exploratory study in the Distrito Federal, central Brazil. Journal of environmental management, 54, 321-334.

Mistry, J., Bilbao, B., \& Berardi, A. (2016). Community owned solutions for fire management in tropical ecosystems: Case studies from indigenous communities of South America. Philosophical Transactions of the Royal Society B: Biological Sciences, 371.

Moran, E. F. (1993). Through Amazonian eyes: The human ecology of Amazonian populations. Iowa City, Iowa: University of Iowa Press.

Moran, E. F., Adams, R., Bakoyema, B. T. S. F, \& Boucek, B. (2006). Human strategies for coping with El Nino related drought in Amazonia. Climatic Change, 77, 343-361.

Morello, T. F., Parry, L., Markusson, N., \& Barlow, J. (2017). Policy instruments to control Amazon fires: A simulation approach. Ecological Economics, 138, 199-222.

Murrieta, R. S. S., \& WinklerPrins, A. M. G. A. (2003). Flowers of water: Homegardens and gender roles in a Riverine Caboclo community in the lower Amazon. Brazil. Culture \& Agriculture, 25, 35-47.

Nelson, A., \& Chomitz, K. M. (2011). Effectiveness of strict vs. multiple use protected areas in reducing tropical forest fires: A global analysis using matching methods. PLoS ONE, 9.

Nepstad, D., Carvalho, G., Barros, A. C., Alencar, A., Capobianco, J. P., Bishop, J., \& Prins, E. (2001). Road paving, fire regime feedbacks, and the future of Amazon forests. Forest Ecology and Management, 154, 395-407. 
Nepstad, D., Schwartzman, S., Bamberger, B., Santilli, M., Ray, D., Schlesinger, P., \& Rolla, A. (2006). Inhibition of Amazon deforestation and fire by parks and indigenous lands. Conservation Biology, 20, 65-73.

Nepstad, D. C., Stickler, C. M., Soares, B., \& Merry, F. (2008). Interactions among Amazon land use, forests and climate: Prospects for a nearterm forest tipping point. Philosophical Transactions of the Royal Society B-Biological Sciences, 363, 1737-1746.

Nobre, C. A., Sampaio, G., Borma, L. S., Castilla-Rubio, J. C., Silva, J. S., \& Cardoso, M. (2016). Land-use and climate change risks in the Amazon and the need of a novel sustainable development paradigm. Proceedings of the National Academy of Sciences, 113, 10759-10768.

Padoch, C., \& Pinedo-Vasquez, M. (2010). Saving slash-and-burn to save biodiversity. Biotropica, 42, 550-552.

Pedroso, N. N. Jr, Murrieta, R. S. S., \& Adams, C. (2008). A agricultura de corte e queima: um sistema em transformação. Bol. Mus. Para. Emílio Goeldi. Ciências Humanas, Belém, 3, 153-174.

Persha, L., Agrawal, A., \& Chhatre, A. (2011). Social and ecological synergy: Local rulemaking, forest livelihoods, and biodiversity conservation. Science, 331, 1606-1608.

Phelps, J., Webb, E. L., \& Agrawal, A. (2010). Does REDD+ threaten to recentralize forest governance? Science, 328, $312-313$.

Phillips, O. L., Aragão, L. E. O. C., Lewis, S. L., Fisher, J. B., Lloyd, J., López-González, G., \& Torres-Lezama, A. (2009). Drought sensitivity of the Amazon rainforest. Science, 323, 1344-1347.

Queiroz, H. L. (2005). A reserva de desenvolvimento sustentável Mamirauá. Estudos avançados, 19, 183-203.

Queiroz, H. L., \& Peralta, N. (2006). Reserva de Desenvolvimento Sustentável: Manejo integrado dos recursos naturais e gestão participativa. In I. Garay \& B. K. Becker (Orgs). Dimensões humanas da biodiversidade (pp. 447-476). Petrópolis, RJ: Vozes, 2006.

RibeiroFilho, A., Ribeiro, A. A., Adams, C., \& Murrieta, R. S. S. (2013). The impacts of shifting cultivation on tropical forest soil: A review. Boletim Do Museu Paraense Emílio Goeldi. Ciências Humanas, 8, 693-727.

Ricketts, T. H., Soares-Filho, B., da Fonseca, G. A. B., Nepstad, D., Pfaff, A., Petsonk, A., Anderson, A., Boucher, D., Cattaneo, A., Conte, M., Creighton, K., Linden, L., Maretti, C., Moutinho, P., Ullman, R., \& Victurine, R. (2010). Indigenous lands, protected areas, and slowing climate change. PLoS Biology, 8, e1000331.

Rodrigues, E. (2011). Em 2012, Acre vai banir as queimadas. Rio Branco, Brazil: Partido Verde do Acre.

Röling, N. G., Leeuwis, C., \& Pyburn, R. (2002). Wheelbarrows full of frogs: Social learning in rural resource management. Assen, Netherlands: Koninklijke Van Gorcum.

Schmidt, I., Fonseca, C., Ferreira, M., \& Sato, M. (2016). Experiências internacionais de manejo integrado do fogo em áreas protegidas-recomendações para implementação de manejo integrado de fogo no Cerrado. Biodiversidade Brasileira, 6, 41-54.

Schmink, M., \& Wood, C. (1992). Contested frontiers in Amazonia. New York, NY: Columbia University Press.

Shannon, N. K., Loretta, J. M., Miriam, E. M., Jonathan, J. B., Patrick, S. K., Tianjia, L., Sulprizio, M. P., DeFries, R. S., Jacob, D. J., Schwartz, J., Pongsiri, M., \& Samuel, S. M. (2016). Public health impacts of the severe haze in Equatorial Asia in September-October 2015: Demonstration of a new framework for informing fire management strategies to reduce downwind smoke exposure. Environmental Research Letters, $11,094023$.

Silvestrini, R. A., Soares-Filho, B. S., Nepstad, D., Coe, M., Rodrigues, H., \& Assuncao, R. (2011). Simulating fire regimes in the Amazon in response to climate change and deforestation. Ecological Applications, 21, 1573-1590.

Sletto, B. (2008). The knowledge that counts: Institutional identities, policy science, and the conflict over fire management in the Gran Sabana. Venezuela. World Development, 36, 1938-1955.

Sletto, B., \& Rodriguez, I. (2013). Burning, fire prevention and landscape productions among the Pemon, Gran Sabana, Venezuela: Toward an intercultural approach to wildland fire management in Neotropical Savannas. Journal of Environmental Management, 115, $155-166$.

Smith, L. T., Aragão, L. E. O. C., Sabel, C. E., \& Nakaya, T. (2014). Drought impacts on children's respiratory health in the Brazilian Amazon. Scientific Reports, 4, 3726.

Soares-Filho, B., Moutinho, P., Nepstad, D., Anderson, A., Rodrigues, H., Garcia, R., \& Maretti, C. (2010). Role of Brazilian Amazon protected areas in climate change mitigation. Proceedings of the National Academy of Sciences of the United States of America, 107, $10821-10826$.

Soares-Filho, B., Silvestrini, R., Nepstad, D., Brando, P., Rodrigues, H., Alencar, A., \& Stickler, C. (2012). Forest fragmentation, climate change and understory fire regimes on the Amazonian landscapes of the Xingu headwaters. Landscape Ecology, 27, 585-598.

Sommer, R., Vlek, P. L. G., Sa, T. D. D., Vielhauer, K., Coelho, R. D. R., \& Folster, H. (2004). Nutrient balance of shifting cultivation by burning or mulching in the Eastern Amazon - evidence for subsoil nutrient accumulation. Nutrient Cycling in Agroecosystems, 68, $257-271$.

Sorrensen, C. (2009). Potential hazards of land policy: Conservation, rural development and fire use in the Brazilian Amazon. Land Use Policy, 26, 782-791.

Steward, A. (2007). "Nobody farms here anymore: livelihood diversification in the Amazonian community of Carvão, a historical perspective. Agriculture and Human Values, 24, 75-92.

Steward, A. M., Rognant, C., \& Vieira do Brito, S. (2016). Roça sem fogo: A visão de agricultores e técnicos sobre uma experiência de manejo na Reserva de Desenvolvimento Sustentável Amanã, Amazonas. Brasil. Biodiversidade Brasileira, 6, 71-87.

Toomey, A., Knight, A. T., \& Barlow, J. (2016). Navigating the space between research and implementation in conservation. Conservation Letters, 00, 1-7.

VanVliet, N., Adams, C., Vieira, I., Guimarães, C., \& Mertz, O. (2013). Slash and burn' and 'shifting' cultivation systems in forest agriculture frontiers from the Brazilian Amazon. Society \& Natural Resources, 26, 1454-1467. 
Vasan, S. (2002). Ethnography of the forest guard: Contrasting discourses, conflicting roles and policy implementation. Economic and Political Weekly, 37, 4125-4133.

Viana, C., Coudel, E., Barlow, J., Ferreira, J., Gardner, T., \& Parry, L. (2016). How does hybrid governance emerge? Role of the elite in building a green municipality in the Eastern Brazilian Amazon. Environmental Policy and Governance, 26, 337-350.

Wunder, S. (2005). Payments for environmental services: Some nuts and bolts Occasional paper (Vol. 42). Bogor, Indonesia: CIFOR.

How to cite this article: Carmenta R, Coudel E, Steward AM. Forbidden fire: Does criminalising fire hinder conservation efforts in swidden landscapes of the Brazilian Amazon?. Geogr J. 2018;00:1-15. https://doi.org/ 10.1111/geoj.12255 